\title{
Plasmodium ovale wallikeri in Western Lowland Gorillas and Humans, Central African Republic
}

\section{Mwanahamisi I. Mapua, ${ }^{1}$ Hans-Peter Fuehrer, ${ }^{1}$ Klára J. Petrželková, Angelique Todd, Harald Noedl, Moneeb A. Qablan, David Modrý}

Author affiliations: University of Veterinary and Pharmaceutical Sciences, Brno, Czech Republic (M.I. Mapua, M.A. Qablan, D. Modrý); University of Veterinary Medicine, Vienna, Austria (H.-P. Fuehrer); Czech Academy of Sciences, Brno (K.J. Petrželková); Liberec Zoo, Liberec, Czech Republic (K.J. Petrželková); Czech Academy of Sciences, České Budějovice, Czech Republic (K.J. Petrželková, D. Modrý); World Wildlife Fund, Bangui, Central African Republic (A. Todd); Medical University of Vienna ( $\mathrm{H}$. Noedl); United Arab Emirates University, Al Ain, United Arab Emirates (M.A. Qablan)

DOI: https://doi.org/10.3201/eid2408.180010

Human malaria parasites have rarely been reported from free-ranging great apes. Our study confirms the presence of the human malaria parasite Plasmodium ovale wallikeri in western lowland gorillas and humans in Dzanga Sangha Protected Areas, Central African Republic, and discusses implications for malaria epidemiology.

$\mathrm{T}$ he transmission of infectious diseases between wild animals and humans is a dynamic process in which wildlife populations have been a major source of zoonotic diseases. Six human malaria parasite species have been recognized during the past decade: Plasmodium falciparum, $P$. vivax, $P$. malariae, $P$. knowlesi, $P$. ovale curtisi, and $P$. ovale wallikeri. The role of human malaria parasites as zoonotic agents in free-ranging great apes remains unclear. Various Plasmodium species have been documented in great apes by using molecular data, including $P$. praefalciparum, $P$. adleri, and $P$. blacklocki in western lowland gorillas (Gorilla gorilla gorilla) (1). Moreover, parasites closely related to human malaria parasites (e.g., $P$. ovale-like and $P$. vivax-like) have been identified in other free-ranging great apes (2). Although contact between free-ranging gorillas and humans has increased steadily, no shared malaria parasites have previously been reported in humans and gorillas. A recent study of western lowland gorillas revealed a unique case of $P$. ovale infection, based on amplification of the mitochondrial cytochrome $\mathrm{b}(\mathrm{cytb})$ gene from gorilla fecal samples (1). To clarify the implications of possible

${ }^{1}$ These authors contributed equally to this article. co-circulation of malaria parasites in humans and gorillas, we reevaluated human blood and western lowland gorilla fecal samples from the previous study using state-of-the-art molecular tools.

Dzanga Sangha Protected Areas is located in southwestern Central African Republic, bordering the Democratic Republic of the Congo in the east and Cameroon in the west. We collected 131 gorilla fecal samples during August-October 2012 from 2 habituated western lowland gorilla groups and from several unhabituated gorillas around the Primate Habituation Programme camps of Mongambe and Bai Hakou. We collected human blood samples in 2012 as part of a health monitoring program for National Park and Primate Habituation Project employees. We received 95 blood samples from asymptomatic participants.

We performed PCR within the nuclear $18 \mathrm{~S}$ small subunit ribosomal RNA gene, as previously described $(3,4)$. This gene is the most commonly used for diagnosis of $P$. falciparum, $P$. vivax, $P$. malariae, $P$. ovale (primers rOVA1WC/rOVA2WC), $P$. ovale curtisi (rOVA1/rOVA2), P. ovale wallikeri (rOVA1v/rOVA2v), and P. knowlesi in humans. We amplified parts of the mt cytb gene to obtain $\approx 939$-bp fragments $(1)$. We also analyzed a shorter fragment of $\approx 480 \mathrm{bp}$ with hemosporidian-specific primers (5). We used a hemosporidian-specific nested PCR performed within the mitochondrial cytochrome $\mathrm{c}$ oxidase subunit 1 gene (primers: cox $1 \mathrm{a} / \operatorname{cox} 1 \mathrm{~b}$ and cox $1 \mathrm{c} / \operatorname{cox} 1 \mathrm{~d})$ to amplify a 964-bp fragment (6). For further analysis of $P$. ovale, we used the primers Porbp2TMfwd/Porbp2TMrev, binding a 120-bp fragment of the nuclear $P$. ovale reticulocyte binding protein 2 gene (7).

Overall, 23 out of 95 (24.2\%; 95\% CI 16.7\%-33.7\%) asymptomatic human samples had positive results in Plasmodium-specific PCRs. Species-specific analysis revealed P. falciparum monoinfections in 19 cases $(20 \%$; $95 \%$ CI $13.2 \%-29.1 \%)$ and $P$. ovale wallikeri in 2 cases $(2.1 \%$; $95 \%$ CI $0.6 \%-7.3 \%$ ). We found a mixed infection of $P$. falciparum and P. malariae (2.1\%; 95\% CI $0.6 \%-7.3 \%$ ) in 2 samples. In the previous study, 42 of 131 fecal samples from western lowland gorillas tested positive for Plasmodium parasites, namely $P$. adleri $(\mathrm{n}=21), P$. praefalciparum $(\mathrm{n}=9)$, and P. blacklocki $(\mathrm{n}=7)$, but also $P$. ovale-like (n $=1)$ and $P$. vivax - like $(\mathrm{n}=3)(1)$. In this study, reevaluating the gorilla fecal DNA extracts for human malaria parasites confirmed 1 sample from a habituated individual as positive for $P$. ovale wallikeri. Identical sequences were obtained in $\mathrm{mt}$ cytb (GenBank accession no. KJ930413) and mt cox1 (GenBank accession nos. MG251662, MG251663) with the gorilla $P$. ovale wallikeri isolate and 1 of the human isolates (Figure). The analysis of the nuclear small subunit rRNA and the porbp 2 gene gave positive results only for the human isolate (GenBank accession nos. MG251661, MG255222). 


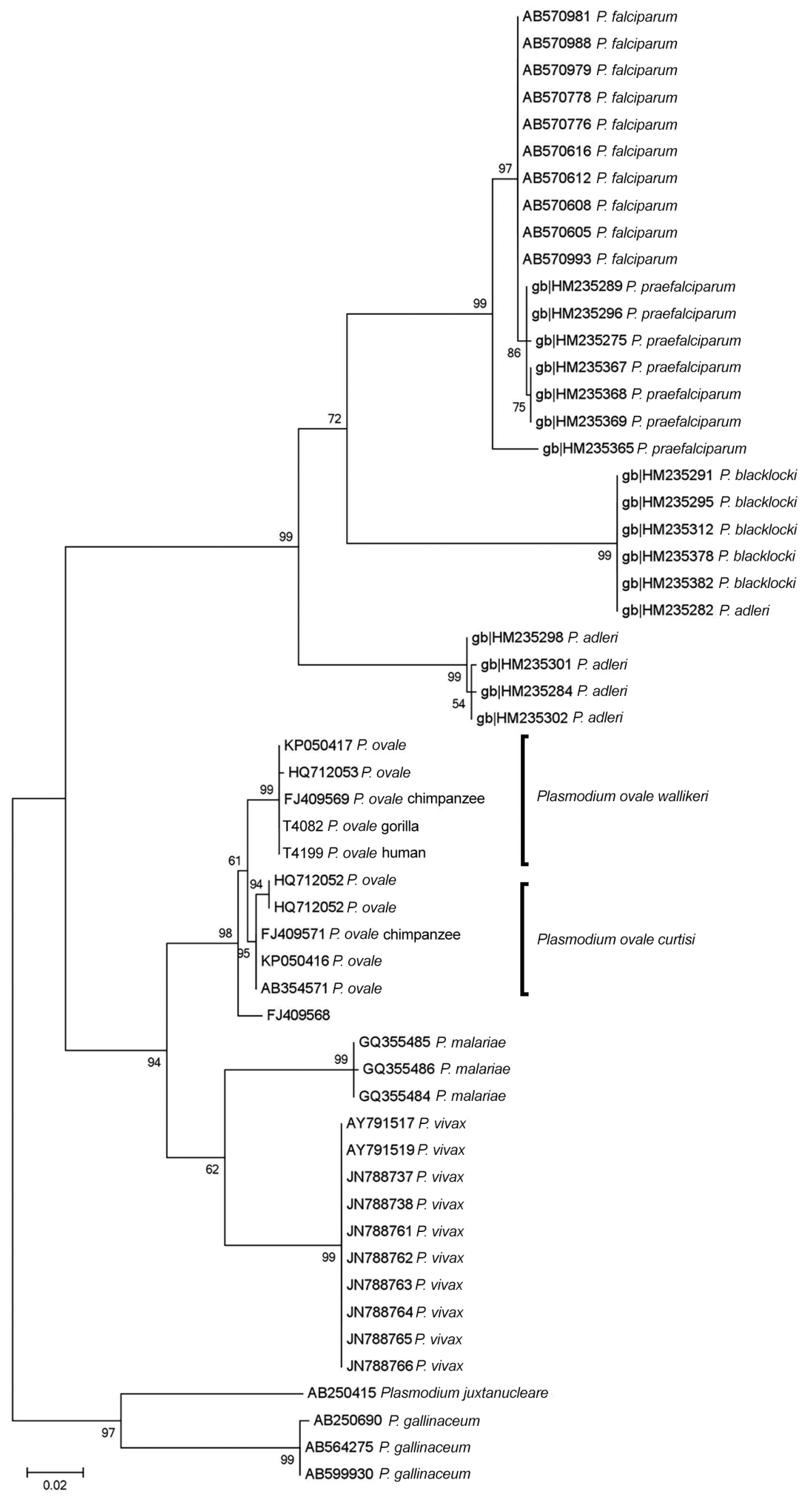

Figure. Maximum-likelihood phylogenetic trees of cytochrome C oxidase subunit 1 ( $\operatorname{cox} 1$ ) gene (656-bp) sequences from African great apes and human Plasmodium spp. reference strains. GenBank accession numbers are indicated. Scale bar represents nucleotide substitutions per site. 
In this study, we found the human malaria parasite $P$. ovale wallikeri in both asymptomatic humans and western lowland gorillas in Dzanga Sangha Protected Areas. Molecular analysis revealed that the genotype of the $P$. ovale wallikeri DNA found in a gorilla was genetically identical to that of a human isolate within the $\mathrm{mt} c y t b$ and $\mathrm{mt}$ cox 1 genes, indicating potential human-ape transmission. Analysis of nuclear genes failed in gorilla feces; thus, it remains unclear which parasite stages can be detected in feces (8). Although the mt cytb and mt cox 1 genes are not the best-suited genes for genotyping human malaria parasites because of their homogeneity, these genes allow clear species discrimination from $P$. ovale-like parasites found in, for example, chimpanzees in Côte d'Ivoire (9) and the Democratic Republic of the Congo (10), which have never been reported in humans. This finding in a western lowland gorilla corroborates a finding of $P$. ovale in a chimpanzee from Cameroon ( $O$ ) with a sequence identical to $P$. ovale wallikeri. However, further studies are required to evaluate the role of great apes as reservoirs of human malaria parasites and vice versa, and the implications of these findings for malaria epidemiology.

\section{Acknowledgments}

We thank Barbara Eigner for her excellent technical support and Colin Sutherland for the critical assessment of the manuscript. We also thank the government of the Central African Republic and the World Wildlife Fund for granting permission to conduct our research in the Central African Republic; the Ministre de l'Education Nationale, de l'Alphabetisation, de l'Enseignement Superieur, et de la Recherche for providing research permits; and the Primate Habituation Project for providing logistical support in the field.

This study was supported by the European Social Fund, the state budget of the Czech Republic (project OPVK CZ.1.07/ 2.3.00/20.0300), and a grant from the Czech Academy of Sciences (IGA 1230-21-IG 121 231).

\section{About the Author \\ Dr. Mapua is a senior researcher in the department of pathology and parasitology at the University of Veterinary and Pharmaceutical Sciences in Brno, Czech Republic. Her research interests include molecular ecology, cross-species transmission of Plasmodium sp., parasitology, and primatology.}

\section{References}

1. Mapua MI, Qablan MA, Pomajbíková K, Petrželková KJ, Hůzová Z, Rádrová J, et al. Ecology of malaria infections in western lowland gorillas inhabiting Dzanga Sangha Protected Areas, Central African Republic. Parasitology. 2015;142:890-900. http://dx.doi.org/10.1017/S0031182015000086

2. Duval L, Fourment M, Nerrienet E, Rousset D, Sadeuh SA, Goodman SM, et al. African apes as reservoirs of Plasmodium falciparum and the origin and diversification of the Laverania subgenus. Proc Natl Acad Sci U S A. 2010;107:10561-6. http://dx.doi.org/10.1073/pnas.1005435107

3. Snounou G, Viriyakosol S, Zhu XP, Jarra W, Pinheiro L, do Rosario VE, et al. High sensitivity of detection of human malaria parasites by the use of nested polymerase chain reaction. Mol Biochem Parasitol. 1993;61:315-20. http://dx.doi.org/ 10.1016/0166-6851(93)90077-B

4. Fuehrer HP, Noedl H, Doern GV. Recent advances in detection of Plasmodium ovale: implications of separation into the two species Plasmodium ovale wallikeri and Plasmodium ovale curtisi. J Clin Microbiol. 2014;52:387-91. PubMed http://dx.doi.org/10.1128/ JCM.02760-13

5. Hellgren O, Waldenström J, Bensch S. A new PCR assay for simultaneous studies of Leucocytozoon, Plasmodium, and Haemoproteus from avian blood. J Parasitol. 2004;90:797-802. http://dx.doi.org/10.1645/GE-184R1

6. Duval L, Nerrienet E, Rousset D, Sadeuh Mba SA, Houze S, Fourment M, et al. Chimpanzee malaria parasites related to Plasmodium ovale in Africa. PLoS One. 2009;4:e5520. http://dx.doi.org/10.1371/journal.pone.0005520

7. Oguike MC, Betson M, Burke M, Nolder D, Stothard JR, Kleinschmidt I, et al. Plasmodium ovale curtisi and Plasmodium ovale wallikeri circulate simultaneously in African communities. Int J Parasitol. 2011;41:677-83. http://dx.doi.org/10.1016/ j.ijpara.2011.01.004

8. Jirků M, Pomajbíková K, Petrželková KJ, Hůzová Z, Modrý D, Lukeš J. Detection of Plasmodium spp. in human feces. Emerg Infect Dis. 2012;18:634-6. http://dx.doi.org/10.3201/ eid1804.110984

9. Kaiser M, Löwa A, Ulrich M, Ellerbrok H, Goffe AS, Blasse A, et al. Wild chimpanzees infected with 5 Plasmodium species. Emerg Infect Dis. 2010;16:1956-9. http://dx.doi.org/10.3201/ eid1612.100424

10. Liu W, Li Y, Learn GH, Rudicell RS, Robertson JD, Keele BF, et al. Origin of the human malaria parasite Plasmodium falciparum in gorillas. Nature. 2010;467:420-5. http://dx.doi.org/10.1038/ nature 09442

Address for correspondence: Hans-Peter Fuehrer, University of Veterinary Medicine Institute of Parasitology, Veterinaerplatz 1, Vienna 1210, Austria; email: hans-peter.fuehrer@vetmeduni.ac.at

\section{gOVDELIVERY \\ Manage your email alerts so you only receive content of interest to you.}

